\title{
PERFORMA AYAM KUB (KAMPUNG UNGGUL BALITBANGTAN) DAN SENTUL TERSELEKSI (SENSI) DENGAN PENGGUNAAN BAHAN PAKAN LOKAL PADA UMUR 0-11 MINGGU DI BALITBANGTAN BPTP SUMATERA UTARA
}

\section{The Performance of Kampung Unggul Balitbangtan (KUB) and Sentul Terseleksi (Sensi) with Local Feed in 0-11 Weeks at Balitbangtan BPTP of North Sumatera}

\author{
Aulia Rahmad Hasyim¹, Alwiyah², Firda Farida Rahma ${ }^{3}$, Khadijah EL Ramija', Khairiah,, dan \\ Yenni Yusriani ${ }^{3}$ \\ 1Balai Pengkajian Teknologi Pertanian (BPTP) Sumatera Utara \\ ${ }^{2}$ Loka Penelitian Kambing Potong Sei Putih \\ ${ }^{3}$ Balai Pengkajian Teknologi Pertanian (BPTP) Aceh \\ Email: aulianursyahhasyim@gmail.com
}

\begin{abstract}
ABSTRAK
Penelitian ini dilaksanakan di Laboratorium Lapang Kandang Ayam KUB Balai Pengkajian Teknologi Pertanian Sumatera Utara. Penelitian ini dilaksanakan pada bulan Januari sampai April tahun 2020. Ayam yang digunakan adalah ayam Kampung Unggul Balitbangtan (KUB) dan Ayam Sentul Terseleksi (Sensi) umur 0-11 minggu sebanyak 80 ekor. Pemeliharaan dilakukan selama 11 minggu. Pakan diberikan secara ad libitum selama pemeliharaan. Pakan komersial (crumble) diberikan pada anak ayam umur sehari (DOC) hingga umur 4 minggu, umur 4-12 minggu diberi perlakuan berupa pakan komersil murni dan campuran pakan lokal. Uji T-test digunakan untuk mengetahui perbedaan penggunaan pakan terhadap bobot badan, pertambahan bobot badan dan mortalitas pada ayam KUB dan ayam Sensi. Berdasarkan hasil penelitian, pakan komersil berpengaruh nyata pada bobot badan ayam Sensi pada umur 9 dan 11 minggu dan umur 5, 8 dan 11 minggu pada ayam KUB. Pakan komersil juga berpengaruh nyata terhadap pertambahan bobot badan pada ayam Sensi. Tingkat kematian ayam Sensi dan KUB pada umur 0-4 minggu mencapai 4-5\% dan umur 4-11 minggu mencapai $2-3 \%$.
\end{abstract}

Kata kunci: Ayam KUB, Ayam Sensi, Pakan lokal, Performa

\begin{abstract}
This research was conducted at KUB Chicken Cage Field Laboratory at North Sumatra Agricultural Technology Research Center. This research was started from January to April 2020. The chickens used were the Balitbangtan (KUB) Superior and Selected Sentul Chickens (Sensi) aged 0-11 weeks, as many as 80 chickens. Maintenance was carried out for 11 weeks. The feed was given ad libitum during maintenance. Commercial feed (crumble) is given to day-old chicks (DOC) up to 4 weeks of age, 4-12 weeks of age and is treated in the form of pure commercial feed and a mixture of local feed. The T-test was used to determine the differences in the use of feed on body weight, body weight gain and mortality in KUB and Sensi chickens. Based on the results of the study, at the age of 9 and 11 weeks, commercial feed had a significant effect on body weight of Sensi chickens and at 5, 8 and 11 weeks of KUB chickens. Commercial feed also has a significant effect on body weight gain in Sensi chickens. The mortality rate of Sensi and KUB chickens aged 0-4 weeks reached 4-5\% and ages 4-11 weeks reached 2-3\%.
\end{abstract}

Keywords: KUB Chicken, Local Feed, Performance, Sensi chicken 


\section{PENDAHULUAN}

Kebutuhan daging ternak di Indonesia semakin meningkat setiap tahunnya. Salah satu penyumbang kebutuhan daging terbesar di Indonesia adalah unggas. Ternak unggas yang umumnya dipelihara oleh masyarakah Indonesia adalah ternak ayam kampung dan ayam broiler. Namun disisi lain pertumbuhan ayam kampung ini cukup lambat hingga mencapai 12 minggu umur panen sedangkan ayam broiler membutuhkan waktu 4 minggu untuk mencapai umur panen. Permasalahan yang terjadi dalam ayam kampung ini salah satunya bisa diatasi dengan menggunakan seleksi ayam kampung dengan potensi genetik yang bagus. Seleksi ayam kampung tersebut kini dikenal dengan nama ayam Kampung unggul Balitbangtan (KUB). Ayam KUB merupakan salah satu jenis ayam kampung hasil inovasi penelitian dari Balai Penelitian Ternak, Ciawi-Bogor (Suryana, 2017). KUB merupakan ayam hasil dari seleksi Ayam Kampung asli Indonesia galur betina (female line) selama enam generasi dan memiliki banyak keunggulan, diantaranya adalah pemberian pakan lebih efisien dengan konsumsinya yang cenderung lebih sedikit, lebih tahan terhadap penyakit, tingkat mortalitas yang lebih rendah, produksi telur Ayam KUB lebih tinggi dengan frekuensi bertelurnya setiap hari (Urfa et al., 2017; Hidayat et al., 2011) sehingga dapat dijadikan solusi pemenuhan kebutuhan protein hewani bagi masyarakat Indonesia.

Usaha ayam ini relatif mudah pemeliharaannya dengan teknologi yang sederhana dan sewaktu-waktu dapat dijual jika ada keperluan rumah tangga yang mendesak (Noferdiman et al., 2014). Yuwono \& Prasetyo (2013) menambahkan bahwa usaha ayam kampung memberikan kinerja yang bagus melalui peningkatan sistem pemeliharaan dari yang awalnya semi intensif menjadi intensif dan mengarah kepada usaha agribisnis. Menurut Damerow (2015) suhu nyaman ayam didaerah tropis adalah $18-28{ }^{\circ} \mathrm{C}$. Tamzil (2014) menambahkan bahwa kelembaban relatif untuk comfort zone ayam adalah 50-70\%. Kini ayam KUB sudah disebarkan ke berbagai wilayah di Indonesia, salah satunya adalah Sumatera Utara melalui Balai Pengkajian Teknologi Pertanian (BPTP) Sumatera Utara. BPTP Sumatera Utara juga sudah menyebarkan ayam KUB ke berbagai daerah di wilayah Sumatera Utara.

Permasalahan yang sering ditemui yaitu ketersediaan pakan ternak. Pakan merupakan kebutuhan utama yang dibutuhkan oleh ternak untuk dapat mempertahankan hidupnya, sekitar $70 \%$ dari kebutuhan produksi. Dalam penyusunan pakan ayam, terlebih dahulu harus diketahui kandungan nutrisi masing- masing bahan pakan, baik kandungan protein kasar maupun zat-zat gizi lainnya (Iskandar et al., 2014). Nilai gizi dalam pakan sangat menentukan hasil produksi dari ternak. Ketersediaan pakan bagi ternak di Sumatera Utara semakin berkurang. Hal ini disebabkan karena adanya persaingan penggunaan pangan dengan pakan sangat tinggi sehingga peluang penyediaan pakan semakin menyempit. Dewasa ini telah banyak peternak rakyat yang gulung tikar karena tidak dapat memenuhi kebutuhan pakan komersial dengan harga tinggi. Untuk itu diperlukan suatu inovasi sehingga penyediaan pakan secara terus-menerus dan tidak bersaing dengan kebutuhan manusia.

Pakan yang berkualitas dan tersedia kontinyu merupakan salah satu faktor penting dalam upaya pengembangan peternakan (Hastuti et al., 2011). Bahan pakan yang biasa digunakan untuk pakan ayam kampung adalah jagung, dedak, tepung ikan, bungkil kedelai, minyak sayur, bungkil kelapa, tepung kapur, hasil ikutan industri pertanian seperti ampas tahu, molases/tetes. Seluruh bahan tersebut dihasilkan di Sumatera Utara. Bahan pakan lokal selalu dikaitkan dengan harga yang murah. Namun ada beberapa hal yang perlu diperhatikan dalam penggunaan bahan pakan, yaitu ketersediaan, kandungan gizi, harga, tidak bersaing dengan manusia dan kemungkinan adanya faktor pembatas seperti zat anti nutrisi. Jumlah bahan yang tersedia di suatu daerah harus diketahui untuk menentukan kelayakan ekonomi dalam penggunaan bahan tersebut. Informasi ini sangat perlu 
dalam perencanaan (formulasi pakan, volume produksi, dan biaya produksi) usaha peternakan. Penulisan makalah ini bertujuan untuk menghasilkan pakan ayam yang berkualitas berbahan pakan lokal untuk meningkatkan pertumbuhan dari ayam Kampung Unggul Balitbangtan (KUB).

\section{METODE}

\section{Waktu dan Lokasi Penelitian}

Penelitian dilaksanakan pada bulan Januari sampai April tahun 2020. Di Laboratorium Lapang Kandang Ayam KUB di Balai Pengkajian Teknologi Pertanian Sumatera Utara.

\section{Metode Penelitian}

Materi yang digunakan dalam penelitian ini adalah ayam Kampung Unggul Balitbangtan (KUB) dan Ayam Sentul Terseleksi (Sensi) Jantan umur 0-11 minggu sebanyak 80 ekor. Pemeliharaan ayam KUB dan Sensi dilakukan selama 11 minggu. Kandang yang digunakan yaitu kandang litter sebanyak 80 petak dengan ukuran tiap petak panjang x lebar x tinggi ( $50 \times 50 \times 60$ ) cm dengan tiap petak kandang diisi 1 ekor ayam.

\section{Metode Penelitian}

Metode yang digunakan pada penelitian ini adalah Uji T secara deskriptif dengan menyajikan rataan (x), simpangan baku (sb). Uji T digunakan untuk mengetahui perbedaan rataan bobot badan, pertambahan bobot badan, dan mortalitas antara Ayam KUB dan Sensi. Delapan puluh ekor ayam dalam penelitian ini dibagi menjadi dua kelompok (P0 dan P1) dengan dua puluh ulangan dengan perlakuan berupa penggunaan pakan yang berbeda.

\section{Pemberian Pakan}

Pakan diberikan ad libitum selama pemeliharaan. Pakan komersial (crumble) diberikan pada anak ayam umur sehari (DOC) sampai umur 4 minggu. Ada dua pakan perlakuan yaitu perlakuan P0 $=100 \%$ crumble untuk ayam ras pedaging fase starter dan perlakuan P1 $=100 \%$ pakan campuran lokal. Tabel 1 merupakan persentase komposisi bahan pakan yang digunakan dan Tabel 2 Kandungan pakan yang digunakan selama penelitian.

Tabel 1. Persentase Komposisi Bahan Pakan yang digunakan selama Penelitian

\begin{tabular}{lc}
\hline Bahan Pakan & Persentase \\
\hline Jagung & 30 \\
Dedak & 20 \\
Roti & 20 \\
Pellet (Reject) & 15 \\
Tepung ikan Lokal & 10 \\
Tepung Kapur & 2 \\
Premix & 1 \\
Garam & 1 \\
Molases & 1 \\
\hline Total & 100 \\
\hline
\end{tabular}

Sebelum penelitian sample pakan di analisis untuk mengetahui kandungan nutrien di dalamnya. Berikut hasil analisis tersedia pada Tabel 2. 
Tabel 2. Kandungan nutrien pakan yang digunakan

\begin{tabular}{lcc}
\hline Komposisi & Analisis Pakan Komersial & Pakan Campuran Lokal \\
\hline Kadar Air & 13 & 10,79 \\
Abu & 8 & 10,87 \\
Protein kasar & $20-22$ & 18,22 \\
Serat kasar & 4 & 7,21 \\
Lemak kasar & $4-8$ & 6,03 \\
Ca & $0,9-1,2$ & 1,38 \\
P & $0,7-1,0$ & 0,63 \\
EM (kkal/g-1) & $2900-3000$ & - \\
\hline
\end{tabular}

Pakan Campuran Lokal Hasil Analisa metode Near Infrared Spectroscopy.

\section{Peubah}

Peubah yang diukur sejak ayam berumur sehari (DOC) sampai ayam berumur 11 minggu yaitu:

1. Bobot badan (BB) dalam satuan gram per minggu per ekor;

2. Pertambahan bobot badan (PBB) dalam satuan g/ekor/minggu

$\mathrm{PBB}=\mathrm{BB}$ pada saat penimbangan - BB pada penimbangan minggu sebelumnya;

3. Mortalitas $(\%)=\frac{\Sigma \text { ayam mati }}{\Sigma \text { ayam awal }} \times 100 \%$

\section{Analisis Data}

Data di analisis secara deskriptif dengan menyajikan rataan $(x)$, simpangan baku (sb). Uji T digunakan untuk mengetahui perbedaan rataan bobot badan, pertambahan bobot badan, dan mortalitas antara Ayam KUB dan Sensi. Berikut rumus uji T menurut Walpole (1993):

$$
t=\frac{\left(\bar{x}_{a}-\bar{x}_{b}\right)-\left(\mu_{a}-\mu_{b}\right)}{\sqrt{\frac{s b_{a}{ }^{2}}{\mathrm{n}_{a}}+\frac{s b_{b}{ }^{2}}{\mathrm{n}_{b}}}}
$$

$$
\begin{aligned}
& \text { Keterangan: } x \mathrm{a}=\text { rataan sampel a sba }=\text { simpangan baku a } \\
& x \mathrm{~b}=\text { rataan sampel } \mathrm{b} \quad \mathrm{sbb}=\text { simpangan baku } \mathrm{b} \\
& \mu \mathrm{a}=\text { rataan populasi a na }=\text { jumlah sampel } \mathrm{a} \\
& \mu b=\text { rataan populasi } b \quad n b=\text { jumlah sampel } b
\end{aligned}
$$

\section{HASIL DAN PEMBAHASAN}

\section{Pertambahan Bobot Badan Ayam KUB}

Bobot badan merupakan indikator penilaian produktivitas dan keberhasilan manajemen dari suatu usaha peternakan. Bobot awal didapat dengan cara penimbangan DOC sedangkan bobot akhir (panen) didapat dari rata-rata bobot badan ayam pada saat dipanen. Pertambahan bobot badan diperoleh melalui perbandingan antara selisih bobot akhir (panen) dan bobot awal dengan lamanya pemeliharaan. Perhitungan rataan pertambahan bobot badan dapat dilihat pada Tabel 1 .

Hasil analisis rataan bobot badan ayam KUB dan Sensi menunjukkan tidak adanya perbedaan, atau dapat dikatakan ratan bobot badan kedua ayam tersebut sama. Seiring dengan bertambahnya umur, bobot badan juga mengalami kenaikan. Berbeda dengan penelitian Suryana et al. (2014) yang menyatakan bahwa bobot badan ayam KUB di umur 4 minggu adalah $500 \mathrm{~g}$ untuk jantan dan $475 \mathrm{~g}$ untuk betina. Grafik rataan bobot badan ayam Ayam KUB dan Sensi dapat dilihat pada Gambar 1 . Pada gambar grafik tersebut menjelaskan rataan bobot badan setiap periode (setiap pengamatan) 
lebih tinggi Sensi dibanding KUB, hal tersebut dapat disebabkan oleh masih besarnya keragaman kapasitas tumbuh individu ayam KUB (Sartika et al., 2013).

Tabel 3. Rataan bobot dan pertambahan badan ayam KUB dan Sensi umur 0-4 minggu

\begin{tabular}{crrrr}
\hline \multirow{2}{*}{ Minggu ke } & \multicolumn{2}{c}{ Bobot Badan $(\mathrm{g})$} & \multicolumn{2}{c}{ Pertambahan Bobot Badan $(\mathrm{g})$} \\
\cline { 2 - 5 } & \multicolumn{1}{c}{ Ayam Sensi } & \multicolumn{1}{c}{ Ayam KUB } & \multicolumn{1}{c}{ Ayam Sensi } & \multicolumn{1}{c}{ Ayam KUB } \\
\hline 0 & $30,467 \pm 2,626$ & $30,778 \pm 2,565$ & 0 & 0 \\
1 & $62,11 \pm 18,34$ & $58,54 \pm 17,81$ & $31,03 \pm 18,18$ & $28,00 \pm 18,26$ \\
2 & $120,16 \pm 29,39$ & $128,73 \pm 30,07$ & $51,30 \pm 38,71$ & $66,85 \pm 25,78$ \\
3 & $156,59 \pm 35,13$ & $157,50 \pm 36,27$ & $35,65 \pm 40,41$ & $28,79 \pm 40,41$ \\
4 & $250,34 \pm 44,81$ & $237,16 \pm 51,03$ & $97,05 \pm 48,21$ & $82,20 \pm 42,57$ \\
\hline
\end{tabular}

Pertumbuhan bobot badan pada Tabel 3 menunjukkan tidak adanya perbedaan yang nyata antara ayam KUB dan Sensi yang diberi pakan komersil maupun pakan lokal. Pertambahan bobot badan yang tertinggi terjadi pada ayam Sensi di umur 4 minggu yaitu mencapai 97,05 g.

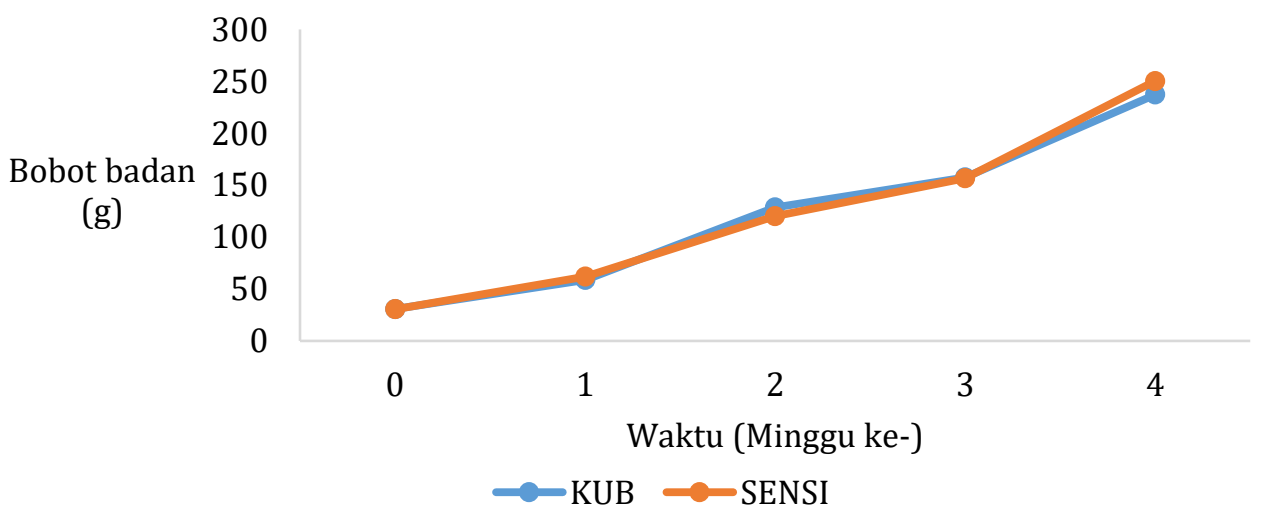

Gambar 1. Grafik bobot badan ayam KUB dan Sensi pada umur 0-4 minggu

Rataan bobot dan pertumbuhan ayam KUB dan Sensi umur 5-11 minggu dibedakan berdasarkan pakan yang digunakannya. Rataan bobot dan pertumbuhan badam ayam KUB dan Sensi ditampilkan pada Tabel 4. Ayam KUB maupun ayam Sensi yang diberi pakan komersil dan pakan lokal mengalami peningkatan bobot badan. Pada perlakuan P0 ayam Sensi memiliki bobot badan yang lebih tinggi jika dibandingkan dengan ayam KUB di umur 11 minggu. Perlakuan pakan yang diberikan pada ayam KUB dan ayam Sensi menunjukkan adanya pengaruh yang nyata pakan terhadap bobot badan ayam Sensi di umur 9 minggu dan pada ayam KUB di umur 8 minggu.

Tabel 4. Rataan bobot dan pertambahan badan ayam KUB dan Sensi umur 5-11 minggu

\begin{tabular}{|c|c|c|c|c|c|c|c|c|}
\hline \multirow{3}{*}{$\begin{array}{l}\text { Minggu } \\
\text { ke- }\end{array}$} & \multicolumn{4}{|c|}{ Bobot Badan } & \multicolumn{4}{|c|}{ Pertambahan Bobot Badan } \\
\hline & \multicolumn{2}{|c|}{ Ayam Sensi } & \multicolumn{2}{|c|}{ Ayam KUB } & \multicolumn{2}{|c|}{ Ayam Sensi } & \multicolumn{2}{|c|}{ Ayam KUB } \\
\hline & P0 & P1 & P0 & P1 & P0 & $\mathrm{P} 1$ & P0 & $\mathrm{P} 1$ \\
\hline 5 & $360,6 \pm 40,3$ & $340,7 \pm 28,1$ & $381,4 \pm 62$ & $333,4 \pm 43,8$ & $114,1 \pm 17,9$ & $94,8 \pm 48,4$ & $125,9 \pm 24,3$ & $119,0 \pm 53,6$ \\
\hline 6 & $638,8 \pm 86,5$ & $631,1 \pm 75,7$ & $578,2 \pm 71,5$ & $552,9 \pm 34,5$ & $277,9 \pm 96,9$ & $291,1 \pm 82,2$ & $196,8 \pm 95,8$ & $219,2 \pm 59,1$ \\
\hline 7 & $737,7 \pm 81,3$ & $736,0 \pm 85,7$ & $675,4 \pm 53,3$ & $646,8 \pm 35,7$ & $98,5 \pm 55,2$ & $109,7 \pm 60,1$ & $100,4 \pm 56,4$ & $87,6 \pm 50,3$ \\
\hline 8 & $887,4 \pm 87,1$ & $829,6 \pm 84,7$ & $788,8 \pm 72,6 a$ & $726,7 \pm 47,9$ & $108,1 \pm 57,9$ & $101,6 \pm 20,8$ & $112,3 \pm 37,9$ & $79,9 \pm 42,0$ \\
\hline 9 & $994,1 \pm 118,5$ & $913,5 \pm 84,7$ & $911,9 \pm 101,6$ & $832,3 \pm 94,4$ & $106,4 \pm 59,1$ & $76,2 \pm 39,1$ & $123,1 \pm 54,1$ & $105,6 \pm 66,5$ \\
\hline 10 & $1100,0 \pm 104,1$ & $1031,4 \pm 84,9$ & $1031,7 \pm 105,8$ & $951,9 \pm 81,6$ & $113,3 \pm 50,9$ & $130,3 \pm 40,9$ & $123,9 \pm 53,7$ & $109,5 \pm 47,0$ \\
\hline 11 & $1235,1 \pm 92,8$ & $1148,9 \pm 108,2$ & $1168,5 \pm 98,6$ & $1075,2 \pm 94,4$ & $150,0 \pm 82,5$ & $105,3 \pm 59,4$ & $130,0 \pm 50,8$ & $139,1 \pm 54,3$ \\
\hline
\end{tabular}

Angka yang disertai huruf yang berbeda pada baris yang sama menunjukkan berbeda 
Pertambahan bobot badan menunjukkan peningkatan seiring bertambahnya umur. Pada pertambahan bobot badan perlakuan pakan memberikan pengaruh yang nyata terhadap pertambahan bobot badan ayam Sensi di umur 9 minggu. Meskipun dari tabel tersebut peningkatan bobot badan baik pada ayam KUB maupun ayam Sensi mengalami fluktuatif. Dalam hal ini pakan lokal yang digunakan dalam penelitian ini merupakan pakan yang dibuat dengan memanfaatkan bahan baku pakan yang ada. menurut Leeson \& Summers (2001), bahwa pertambahan bobot badan sangat dipengaruhi oleh konsumsi pakan. Untuk mencapai pertumbuhan yang maksimal harus didukung pemenuhan nutrisi (Darwati \& Martojo 2001). Soeparno (1998) menyatakan bahwa pada fase pertumbuhan terjadi perubahan ukuran yang meliputi perubahan berat hidup, bentuk, dimensi linier dan komposisi tubuh, termasuk perubahan komponen-komponen tubuh seperti otot lemak, tulang dan organ serta komponen-komponen kimia, terutama air, lemak, protein, dan abu pada karkas.

\section{Mortalitas}

Saat pemeliharaan terdapat beberapa ayam yang mengalami kematian. Berikut persentase mortalitas Ayam KUB dan Sensi pada umur 0-11 minggu disajikan pada Tabel 5.

Tabel 5. Persentase kematian Ayam KUB dan Sensi umur 0-11 minggu

\begin{tabular}{ccccc}
\hline Umur (Minggu) & Perlakuan & Jenis Ayam & Populasi (ekor) & Mortalitas (\%) \\
\hline $0-4$ & - & KUB & 40 & $5(10,00)$ \\
& - & Sensi & 40 & $4(13,00)$ \\
\hline $5-11$ & P0 & KUB & 18 & $2(11,11)$ \\
& P1 & & 18 & $2(11,11)$ \\
& P0 & Sensi & 18 & $3(16,67)$ \\
& P1 & & 16 & $2(12,50)$ \\
\hline
\end{tabular}

Persentase mortalitasa ayam KUB dan Sensi pada umur 0-4 minggu masing-masing adalah 10\% dan 13\%. Hal ini tidak berbeda jiks dibandingkan dengan penelitian Priyanti et al. (2016), yaitu rata-rata mortalitas ayam KUB sampai dengan umur enam minggu sebesar lebih dari 5\%. Mortalitas pada ayam umur 0-4 minggu karena ayam masih belum bisa beradaptasi dengan baik dan rentan terhadap penyakit dan diduga karena brooder tidak menghasilkan panas yang merata dan berakibat stres pada ayam. Mortalitas pada ayam KUB dan Sensi baik pakan komersil maupun pakan lokal berkisar 11,11\% hingga 16,67\%.

Selanjutnya Suprijatna et al. (2005) menyatakan bahwa penyakit yang sering menyerang ternak disebabkan oleh cekaman (stres), defisiensi pakan, protozoa, bakteri, virus, dan cendawan. Zainal et al. (2012) mengungkapkan 15 bahwa tingkat mortalitas dapat dikurangi melalui perbaikan manajemen meliputi sistem pemeliharaan, pakan, perbaikan sanitasi dan lingkungan yang bersih.

\section{KESIMPULAN}

Pakan komersil berpengaruh nyata pada bobot badan ayam Sensi pada umur 9 dan 11 minggu dan umur 5, 8 dan 11 minggu pada ayam KUB. Pakan komersil juga berpengaruh nyata terhadap pertambahan bobot badan pada ayam Sensi. Tingkat kematian ayam Sensi dan KUB di umur 0-4 minggu mencapai 4-5\% dan umur 4-11 minggu mencapai 2-3\%. 


\section{DAFTAR PUSTAKA}

Damerow, G. (2015). The Chicken Health Handbook: A Complete Guide to Maximizing Flock Health and Dealing with Disease. $2^{\text {th }}$ Ed. North Adams: Storey Publishing.

Darwati, S. \& Martojo, H. (2001). Persilangan pertumbuhan pelung x kampung pada pemeliharaan intensif. Media Peternakan, 24, 8-11.

Hastuti, D., \& Awami, S. N. (2011). Pengaruh perlakuan teknologi amofer (amoniasi fermentasi) pada limbah tongkol jagung sebagai alternatif pakan berkualitas ternak ruminansia. Mediagro, 7(1).

Hidayat, C., Iskandar, S., \& Sartika, T. (2011). Respon kinerja perteluran ayam Kampung Unggul Balitnak (KUB) terhadap perlakuan protein ransum pada masa pertumbuhan. JITV, 16(2), 8389.

Iskandar, S., Hidayat, C., Sartika, T., \& Resnawati, H. (2014). Optimizing dietary energy and protein for growing "KUB" chicken in supporting maximum egg production. In Proceedings International Seminar on Livestock Production and Veterinary Technology. Bogor (Indonesia): Indonesian Center for Animal Research and Development (pp. 159-164).

Leeson, S. \& Summers, J. D. (2001). Nutrition of The Chicken. 4th Edition. Canada: University Brooks.

Noferdiman, Fatati, \& Handoko, H. (2014). Penerapan teknologi pakan lokal bermutu dan pembibitan ayam kampung menuju kawasan village poultry farming (VPF) di Desa Kasa Lopak Alai Kabupaten Muaro Jambi (Indonesia). J Pengabdian Masyarakat. 29(3), 60-70.

Priyanti, A., Sartika, T., Priyono, Juliyanto, T. D., Bahri, S., \& Tiesnamurti, B. (2016). Kajian Ekonomik dan Pengembangan Inovasi Ayam Kampung Unggul Balitbangtan (KUB). Bogor: Pusat Penelitian dan Pengembangan Peternakan.

Rahmawati, E., Suprijatna, E., \& Sunarti, D. (2017). Pengaruh frekuensi pemberian pakan dan awal pemberian pakan terhadap performa ayam buras super.Jurnal Sain Peternakan Indonesia, 12(2), 152-164.

Sartika, T., Desmayati, Iskandar, S., Resnawati, H., Setioko, A. R., Sumanto, Sinurat, A. P., Isbandi, Tiesnamurti, B., Romjali, E. (2013). Ayam KUB-1. Jakarta: IAARD Press.

Soeparno. (1998). Ilmu dan Teknologi Daging. Cetakan ke-2. Yogyakarta: Gajdah Mada University Press.

Suprijatna, E., Atmomarsono, U., \& Kartasudjana, R. (2005). Ilmu Dasar Ternak Unggas. Jakarta: Penebar Swadaya.

Suryana, Noor, A., Galib, R., Ningsih, R. D., Darmawan, A., \& Sarjini. (2014). Pengkajian pertanian terpadu di lahan rawa lebak Kalimantan Selatan. Laporan Hasil Pengkajian. Banjarbaru: BPTP Kalimantan Selatan.

Suryana. (2017). Development of KUB Chicken in South Kalimantan. Wartazoa-Buletin Ilmu Peternakan dan Kesehatan Hewan Indonesia, 27(1), 45-52.

Tamzil, M. H. (2014). Stres panas pada unggas: metabolisme, akibat dan upaya penanggulangannya. Wartazoa, 24(2), 57-66.

Urfa, S., Indrijani, H., \& Tanwiriah, W. (2017). Model Kurva Pertumbuhan Ayam Kampung Unggul Balitnak (KUB) Umur 0-12 Minggu (Growth Curve Model of Kampung Unggul Balitnak (KUB) Chicken). Jurnal Ilmu Ternak Universitas Padjadjaran, 17(1), 59-66.

Yuwono, D. M., \& Prasetyo, F. R. (2013). Analisis teknis dan ekonomis agribisnis ayam buras sistem semi intensif (Studi kasus di KUB" Ayam Kampung Unggul” Desa Kreseng, Kecamatan Gringsing, Kabupaten Batang). In Dalam: Prosiding Seminar Nasional Menggagas Kebangkitan Komoditas Unggulan Lokal Pertanian dan Kelautan. Madura (Indonesia): Fakultas Pertanian Universitas Trunojoyo Madura. (pp. 17-24).

Zainal, H., Sartika, T., Zainuddin, D., \& Komarudin. (2012). Local chicken crossed of KUB, sentul and gaok to increase national poultry meat production. Workshop Nasional Unggas Lokal. Bogor: Balai Penelitian Ternak. 